\title{
RESISTING LABOUR: UNIONISTS, LIBERALS, AND MODERATES IN GLASGOW BETWEEN THE WARS*
}

\author{
JAMES J. SMYTH \\ University of Stirling
}

A B S T R A C T. This article examines the co-operation between unionists and liberals in inter-war Glasgow. As with the parliamentary challenge of labour, unionists and liberals were confronted at the local level also. The usual response was some sort of municipal alliance or pact. In Scotland, where unionist support for continuing links with liberals was particularly pronounced, this took the form of specific 'moderate' parties created to contest local elections. This strategy was markedly successful in keeping labour out of office. The moderates secured their majority in Glasgow by completely dominating the middle-class wards and winning a number of working-class seats. Moderate success is examined through the essential unity of the middleclass vote, the more limited local franchise, and religious sectarianism. However, it became increasingly difficult for the moderates to satisfy both their middle-class and working-class supporters. The sudden emergence of a militant protestant party in the depths of the depression provided a temporary vehicle of protest, which split the moderate vote and allowed labour in to power in 1933.

In recent years considerable attention has been paid to the fortunes of the Conservative party in the inter-war period. No longer are historians prepared to, as McKibbin puts it, take Conservative success 'for granted' but are analysing and explaining the Tory dominance in both England and Scotland. ${ }^{1}$ The work of such as Williamson, Jarvis, and Hutchison, tends to depict the Conservatives in a more positive light: not simply the unwitting beneficiaries but also the architects of change; not merely reactionary but willing to embrace a degree of social reformism. ${ }^{2}$ Yet, there remains the recognition that, in the post-war years, perhaps

* I would like to thank Iain Hutchison and two anonymous referees for their helpful comments on an earlier draft of this article.

${ }^{1}$ R. I. McKibbin, 'Class and conventional wisdom: the Conservative party and the 'public' in inter-war Britain', in idem, The ideologies of class: social relations in Britain, I880-I950 (Oxford, I99I), p. 259 .

${ }_{2}^{2}$ P. Williamson, Stanley Baldwin: conservative leadership and national values (Cambridge, I999); D. Jarvis, 'British conservatism and class politics in the I920s', English Historical Review, in (I996), pp. 59-84; I. G. C. Hutchison, 'Unionism between the two world wars', in C. M. M. Macdonald, ed., Unionist Scotland, 1800-1997 (Edinburgh, 1998), pp. 87-8. 
up to I929, the political situation was 'extraordinarily fluid'. ${ }^{3}$ What this fluidity suggests to some is that the liberals were not yet dead in the water and that had the 'progressive alliance' of liberal and labour been re-established, this long period of Conservative dominance could have been avoided. This perspective can be found, implicitly, in the work of Biagini and Reid. ${ }^{4}$ It is also the explicit political message in the current writings of the leaders of 'New Labour'. For instance, Tony Blair has quoted approvingly Professor Marquand on the 'progressive dilemma', and Philip Gould clearly identifies the Labour party's adoption of the I9I8 constitution as forcing the break with liberalism. ${ }^{\mathbf{5}}$

Such a position can find (some) comfort in studies which question the supposed inevitability of the rise of labour and its displacement of the Liberal party, and which emphasize the continuing strength of the liberal vote after i9i8. ${ }^{6}$ Yet, it is interesting that the authors of such revisionist pieces themselves question the very notion of a post-war progressive vote. For instance Hart has commented in his critique of Matthew et al. that 'for most of the years I918-26, the Liberals were not progressive'. Tanner identifies both the weakness of the new liberals and their own diminished concern with reform. ${ }^{8}$ And Hutchison remarks of the Scottish liberals that 'they had little to offer the working class and social progressives after I9I8'. 9 This article takes that insight further and argues that any interpretation which posits a labour-liberal alliance after the war misses the point completely, since the essential political divide in the inter-war period both at the national, and, more explicitly, at the local level - was between the right and left, between liberal and conservative on one hand, and labour on the other.

At the end of the First World War the dilemma facing those committed to maintaining the rights of property and the status quo was how to resist the encroaching tide of 'socialism' or 'bolshevism' at home as well as abroad. ${ }^{\mathbf{1 0}}$ Only when the coalition collapsed in $1922 \mathrm{did}$ the hopes of a united party of the

3 The phrase is that of Professor Marquand, in D. Marquand, Ramsay MacDonald (London, I977), p. 792 .

${ }^{4}$ E. F. Biagini and A.J. Reid, eds., Currents of radicalism: popular radicalism, organised labour and party politics in Britain, I850-I9I4 (Cambridge, I99I), p. I9.

5 T. Blair, New Britain: my vision of a young country (London, I996), p. Io; P. Gould, The unfinished revolution; how the modernisers saved the Labour party (London, I998).

6 The 'inevitability' view is expressed in H. Pelling, 'Labour and the downfall of liberalism', in idem, Popular politics and society in late Victorian Britain (London, I979); R. I. McKibbin, The evolution of the Labour party, I9IO-I924 (Oxford, I924); H. G. G. Matthew, R. I. McKibbin, and J. A. Kay, 'The franchise factor in the rise of the Labour party', English Historical Review, 9I (I976), pp. 723-52; C. Cook, The age of alignment: electoral politics in Britain, 1922-1929 (London, I975).

7 M. Hart, 'The Liberals, the war and the franchise', English Historical Review, 97 (I982), p. 826.

8 D. Tanner, Political change and the Labour party, I90o-I9I8 (Cambridge, I990), p. 427.

9 I. G. C. Hutchison, Scottish politics in the twentieth century (Basingstoke, 200I), p. 39.

${ }^{10}$ What Wrigley, paraphrasing Marx, terms 'The spectre haunting Europe'. C. Wrigley, Lloyd George and the challenge of labour: the post-war coalition, I9I8-I922 (Hemel Hempstead, I990), p. I3. 
right finally come to an end. ${ }^{11}$ However, it is clear that even after this, in many areas conservatives and liberals (both 'independent' and 'national') continued to operate de facto electoral pacts. ${ }^{12}$ Alongside such arrangements at the parliamentary level, were more intimate and lasting coalitions operating in municipal politics. ${ }^{13}$

National and local politics can, and often do, operate by different criteria and respond to different issues. For instance, Glasgow and Sheffield witnessed the more or less total collapse of the liberals as a significant parliamentary force after the war and, in both, the anti-labour parties formally united in municipal politics. Yet, in Glasgow a parliamentary majority was achieved by labour as early as I922, whereas this was not achieved in Sheffield until I929. In contrast however, labour secured a municipal majority in Sheffield in I926, some nine years before doing so in Glasgow. ${ }^{14}$ None the less, the two cities did become recognized labour strongholds with the party dominating parliamentary and municipal representation in the late I930s. Moreover, and this is more germane to the argument here, municipal electoral pacts between liberal and conservative made parliamentary arrangements all the more likely. ${ }^{15}$ In Glasgow, as in the other Scottish cities and towns, the arrangements tended towards the formation of a specific local government party, usually termed the 'moderates', though latterly 'progressive' became the favoured title. In England such amalgamations were less usual, though they were constructed in Sheffield, Bristol, and various other towns. ${ }^{16}$

However, the crucial point is that the alliance was always one way - between liberal and conservative - and always for one purpose - to keep labour out of office. This point is reinforced by the multi-volume study of Davies and Morley into the county boroughs of England and Wales. Whatever form the political arrangement took, they conclude that 'It is striking that in all the boroughs considered so far, the political struggle at the municipal level resolved itself quite rapidly after 1918 into more or less a straight fight between labour and anti-labour forces. ${ }^{17}$ The subject of this article is how that alliance was created in Glasgow, why it was so successful for much of the inter-war period, and why it eventually failed. Among the issues that will be examined in this narrative are the political

11 S. Ball, The Conservative party and British politics, I902-195I (London, I995), p. 65. Cowling sees the 1924 election as having 'destroyed all hope of a centre Party', M. Cowling, The impact of Labour, 1920-1924 (Cambridge, I92I), p. 2.

12 Cook, Age of alignment, pp. 287-94; Hutchison, Scottish politics, pp. 46-7.

13 Cook, Age of alignment, chs. 3 and 4; Wrigley, Lloyd George, pp. 243-4.

14 General election information is taken from F. W. S. Craig, British parliamentary election results, I9I8-I949 (Glasgow, I969). For Sheffield municipal politics, see H. Mathers, 'The city of Sheffield I893-I926', and A. Thorpe, 'The consolidation of a labour stronghold', both in C. Binfield et al., eds., The history of the city of Sheffield, I843-1993, I: Politics (Sheffield, I993), pp. 53-84, and pp. 85-I I8.

${ }^{15}$ Cook, Age of alignment, pp. 290-I; Hutchison, Scottish politics, p. 57.

16 Cook, Age of alignment, p. 52; Mathers, 'City of Sheffield'; Thorpe, 'Consolidation'.

17 S. Davies and B. Morley, County borough elections in England and Wales, 19I8-1938: a comparative analysis, II: Bradford-Carlisle (Aldershot, 2000) p. 653 . 
unity of the middle class, the franchise factor, religious sectarianism, and the impact of the depression.

\section{I}

Formal electoral pacts were easier to create in Scotland since municipal politics had been traditionally fought without party labels. ${ }^{18}$ Prior to I9I4 it was labour and socialist aspirants only who identified themselves as in any way party political. Since they only ever represented a minority of candidates they could be regarded or dismissed as somehow foreign to the system. Of course, this nonpolitical screen at elections concealed the fact that party attachments did exist within the Council chambers with loose, though identifiable, groupings of liberals, liberal unionists, and conservatives. Although Glasgow retained its public reputation as a model, reforming local authority, there was an increasing reaction against municipal control and rising rates. The creation of a Citizens' Union in the late I8gos saw an increasing anti-socialist element in Glasgow's local politics, which became more pronounced as labour began to enjoy increased representation in working-class wards in the years before the war. ${ }^{19}$ In a foretaste of the greater polarity of post-war politics, the creation of the Glasgow Labour party in I9I3 saw an anti-socialist alliance, known as the 'moderates', formed to stand against labour candidates. ${ }^{20}$ Elsewhere similar reactions of liberal-conservative co-operation occurred where labour was beginning to make some progress in the municipal polls. ${ }^{21}$

The new political situation in I9I8 witnessed both the rise of labour to a position of independent strength and the almost utter collapse of the Liberal party in Glasgow. The issuing of the 'coupon' by Lloyd George and Bonar Law was particularly harsh on the independent liberals and particularly fortuitous for the unionists. Of the city's fifteen parliamentary constituencies, ten went unionist, three were secured by coalition liberals, and one each by coalition labour and labour. There were no independent liberals returned. It has been shown that Scottish liberalism retained popular support and, indeed, enjoyed resurgence in

18 W. Miller, 'Politics in the Scottish city, $\mathrm{I}_{32}{ }^{-1882}$ ', in G. Gordon, ed., Perspectives of the Scottish city (Aberdeen, I985), p. I8I.

19 I. Maver, Glasgow (Manchester, 2000), pp. I53-6I; see also idem, 'Glasgow's civic government', in W. H. Fraser and I. Maver, eds., Glasgow: II: I830-I9I2 (Manchester, I996), pp. 475-7; J. J. Smyth, Labour in Glasgow, I896-I936: socialism, suffage, sectarianism (East Linton, 2000), pp. 5I, 63, 7I-3.

20 I. Maver [Sweeney], 'Local party politics and the Temperance crusade: Glasgow, I890-I902', Scottish Labour History Society foumal, 27 (1992), pp. 44-63, at p. $5^{8 .}$

21 In Sheffield, 'A municipal alliance between the Conservative and Liberal parties was effectively in existence from I9I3': Mathers, 'City of Sheffield', p. 75. For similar anti-Labour alliances in London, Leicester, and West Yorkshire see P. Thompson, Socialists, Liberals and Labour: the struggle for London, I885-19I4 (London, I967); B. Lancaster, Radicalism, co-operation and socialism: Leicester working class politics, I86o-I9o6 (Leicester, I987); K. Laybourn and J. Reynolds, Liberalism and the rise of Labour, I89o-I9I8 (London, I984). 
I923 when the united party won more seats than the unionists. ${ }^{22}$ However, there was to be no evidence of this in the city they had dominated for most of the previous century; the last liberal seat was lost at the ig23 election.

What is interesting about the Glasgow situation was that in spite of the liberal decline, unionist opinion was overwhelmingly in support of continuing the alliance. At the Carlton Club, a clear majority of Scottish members voted in favour of maintaining the coalition, a view shared more widely within the party with particular fears about what would happen in Glasgow if the association was to end. $^{23}$

The results in I922 showed why the unionists had good reason to seek common cause with the liberals. In a seismic shift of political loyalties, labour secured ten of the Glasgow constituencies, five of which were in three-way contests. Labour's victory in the suburban seat of Cathcart is particularly revealing. A coalition liberal had been successful in I9I8 and a large number of unionists within the constituency protested when a unionist was chosen to run against the new national liberal candidate, the prominent businessman, Sir Andrew Duncan. In the manifesto issued by this group the link between national and municipal elections is clear, 'the time is most inopportune for splitting the moderate vote, and it would be calamitous if as a result of the division, Cathcart should be represented in Parliament by a Labourist or Socialist'. ${ }^{24}$ It was clear that such contests worked to labour's benefit overall. In the elections of I922, I923, and I929 labour won ten seats, whereas in I924, when there were no threecornered contests, labour representation fell back to a more representative eight MPs. The Unionists knew that they had been flattered by the result in I9I 8 and self-preservation made many keen to maintain their alliance with the liberals. Even in I924 it was common knowledge that both parties in Scotland were operating 'secret' pacts in a large number of constituencies. ${ }^{25}$

\section{I I}

If such a strategy made sense and paid dividends at the parliamentary level, the logic was even more pressing when it came to municipal elections. The repulse of labour at the general election in I9I8 was a matter of great satisfaction among right-wing opinion in Glasgow; 'If there was any reason to question the City's allegiance to the Government the ballot box has supplied an answer which is almost staggering in its decisiveness. ${ }^{\mathbf{2} 6}$

22 I. G. C. Hutchison, A political history of Scotland, I832-1924: parties, elections and issues (Edinburgh, I986), pp. 322, 325-8; see also idem, Scottish politics, p. $3^{6 .}$

${ }^{23}$ Idem, Political history, p. 3 I4.

${ }^{24}$ Glasgow Herald, 2 Nov. I922. The municipal poll was on 7 Nov. with the parliamentary contest eight days later.

${ }^{25}$ Hutchison, Political history, pp. $325^{-8}$; G. Brown, 'The Labour party and political change in Scotland: the politics of five elections' (Ph.D., Edinburgh, I982), pp. 335-40.

26 Glasgow Herald, 30 Dec. I9I8. 
However, any sense of well being which this triumph encouraged proved to be short-lived. Within a month Glasgow had embarked upon its most notorious industrial dispute, the forty hours' strike of January I9I9, famously described by the secretary of Scotland as 'a Bolshevist rising' ${ }^{27}$ Whether or not the government's decision to send troops and tanks into Glasgow was 'an exaggerated and panicky reaction', the strike certainly helped consolidate the city's 'red' reputation. ${ }^{28}$ Moreover, Glasgow's particular radicalism existed within a national context of uncertainty about the future. Wrigley has described the 'special mood in I9I9 ... a feeling, widespread in Britain, of fear, or of expectation, that major social change was imminent'. ${ }^{29}$ While Wrigley identifies early I9I9 as the crucial period, it is clear that, for Glasgow and the west of Scotland at any rate, fears of labour's advance, both electoral and industrial, remained at a high pitch for some time thereafter.

It has been argued that the improvement in labour's electoral fortunes, beginning in the summer of 1919 , helped deflate tensions by encouraging a new confidence in political progress through parliamentary means. ${ }^{30}$ However, it is clear that much middle-class and propertied opinion was just as concerned at the prospect of labour progress at the polls as it was of direct action. In his speech to the first annual general meeting of the Scottish Middle-Class Union, its chairman, Sir William MacEwan, argued that only those who paid income tax should have the vote, urged the government to cut back expenditure on education and housing, and 'said it would be well for them to organise now, for other and more menacing strikes were threatening the community' ${ }^{31}$

While it would be mistaken to attach too much attention to this single organization, none the less, the plethora of such bodies is indicative of middle-class fears and attitudes. ${ }^{32}$ Thus, the sentiments expressed above can be taken as representative of middle-class desire for 'economy' in public expenditure - national and local - and a rejection of any commitment to social reform and reconstruction. Such views found confirmation in the columns and editorials of the Scottish press, which was overwhelmingly unionist. ${ }^{33}$ The Glasgow Herald's attitude to elections was one of motivating and directing the anti-labour vote. The following diatribe was penned on the eve of the municipal poll of I9I9 and is worth quoting at length since it represents a common editorial outlook:

${ }^{27}$ Quoted in I. McLean, The legend of red Clydeside (Edinburgh, I983), p. I25.

28 Ibid., p. I20. For an alternative view of Glasgow's industrial militancy see J. Foster, 'Strike action and working class politics on Clydeside, I9I4-I9I9', International Review of Social History, 35 (I990), pp. $33-70$

29 Wrigley, Lloyd George, p. I3.

$30 \mathrm{~S}$. White, 'Ideological hegemony and political control: the sociology of anti-Bolshevism in Britain I9I8-20', Scottish Labour History Society Fournal, 9 (I975), pp. 3-20, at p. I4.

31 Glasgow Herald, 23 Oct. I9I9.

32 On the burgeoning of anti-Bolshevik and pro-property organisations and their links with business, see White, 'Ideological hegemony'; and Wrigley, Lloyd George, pp. i6-i7.

${ }^{33}$ I. G. C. Hutchison, 'Scottish Unionism between the two world wars', in C. M. MacDonald, ed., Unionist Scotland, I80o-I997 (Edinburgh, I998), pp. 8I-2; idem, Scottish politics, pp. 31-2. 
A programme for the exploitation of the 'Haves' in the interest of the 'Have-Nots' will never lack numerical backing. Panem et circenses has always been a good election cry, and the mob will always hoist the tribune on its shoulder if he promises to give it something for nothing ... If they [the citizens] wish, as they ought to wish, to keep the taint of class politics out of the City Chamber - and when all is said, the Labour movement in the municipalities covers a deliberate attack on the middle class - they will deal trenchantly with the men who are making Socialism and the advantage of the proletariat their aim. ${ }^{34}$

Such sentiments have to be placed alongside of any emphases on how after I9I8 conservative rhetoric constructed a 'national' interest or the 'progressive' element of unionism. Whatever efforts may have been made to disseminate propaganda directly, most people were likely to get their political impressions and opinions via the press. More generally, as Davies and Morley have pointed out about the local press in England and Wales, '[it] tended to be stridently partisan in its coverage and continually stress the "dangers of socialism", ${ }^{35}$ The longevity and consistency of this message, before as well as after the war, is worth noting. When labour first emerged as a local political presence in the i8gos the Herald fulminated against 'overwhelming schemes of municipalisation and confiscation', and when labour ultimately secured victory in the I93os, its stridency reached fever pitch: 'Left-wing government will mean prejudiced class administration and an orgy of extravagance. ${ }^{, 36}$

Labour's electoral success continued into the autumn of I9I9 throughout Britain with further by-election successes and unprecedented gains at the municipal polls. Labour returned candidates in areas that had previously been barren ground and even took control of a number of London boroughs. ${ }^{37}$ In Glasgow Labour made four net gains, but preparations were being made for I920 when all three seats in every ward were to be contested.

The results in I9I9, and the prospect of an actual socialist majority the following year, helped concentrate minds on how best to cope with the growing leftwing presence. As early as May igig the Rotary Club had proposed a Good Government League (GGL) for Glasgow and after the municipal election the Citizens' Union got involved in promoting a wider movement, 'to combat the Socialist propaganda in Glasgow'. ${ }^{38}$ Although active in this field prior to I9I4, it was recognized that the task was beyond the capacity of the Citizens' Union on its own and a provisional committee was formed of three delegates from the Glasgow Unionist Association (GUA), the Glasgow Liberal Council, and the Women's Citizens' Association. ${ }^{39}$ This committee in turn invited delegates from other societies and among those joining were the Citizens' Union, the

34 Glasgow Herald, 4 Nov. I9I9. $\quad{ }^{35}$ Davies and Morley, County borough elections, p. 654 .

36 Glasgow Herald, 8 Nov. I893, 8 Nov. I933. $\quad 37$ Wrigley, Lloyd George, p. 245.

38 Glasgow Unionist Association (GUA), 'minute book', General Committee, 22 Dec. igr9. Scottish Conservative and Unionist (SCUA) Archive, National Library of Scotland (NLS) ACC. 10424/73.

${ }^{39}$ NLS, 'Sir Lewis Shedden's file relating to Glasgow municipal elections, I896-I939', ACC. I0424/9 (xii). 
Rotary Club, the City Business Club, the Citizens' Vigilance Association, the YMCA, the National Council of Women, and the Middle-Class Union. ${ }^{40}$

This umbrella organization was first called the Glasgow Municipal Electors' League but this was dissolved and replaced by the Glasgow Good Government Committee (1920). ${ }^{41}$ The choice of title suggests a temporary initiative to counter labour's expected assault on the town council in $1920 .{ }^{42}$ However, it soon became a permanent feature and, as the GGL, was responsible for directing the anti-socialist or 'moderate' efforts at the municipal elections. This it did with notable success as the Moderate party controlled Glasgow corporation until I933. The key to this achievement lay in avoiding any splits in the anti-labour vote. The creation of the league permitted what was an effective alliance of unionists and liberals while maintaining the tradition of 'no politics' in local government.

Within the GUA there were some prominent members who desired to fight local contests directly under their own political colours. ${ }^{43}$ This group was led by Sir Charles Cleland, chairman of the association, who harboured a long-standing resentment at what he took to be the liberals' effective, though hidden, party political approach to municipal affairs. Although there were a number of efforts, going back to the I8gos and earlier, to get the party to run its own candidates, these were always defeated by the wider membership. ${ }^{44}$ If the party as a whole was happier with the no politics approach before I9I4, it is hardly surprising they were keen to maintain that strategy after the war. Thus, rather than follow Cleland's suggestion and fight under their own colours, the Glasgow unionists enthusiastically embraced the concept of a 'broad front' in municipal affairs and successfully submitted the following resolution at the Scottish Conference in October i920:

That the time has come when the Unionist Associations throughout the country, should actively concern themselves in Local Government Elections, and that, acting when possible in combination with other non-Socialist Organisations, they should endeavour to secure the return to Town and County Councils, Parish Councils, and Education Authorities of men and women of sound progressive and anti-Socialist opinions. ${ }^{45}$

The Glasgow unionists, therefore, can be seen as providing a model for the rest of Scotland and municipal contests in the Scottish cities remained largely a duopoly between labour and moderates/progressives until the late ig6os when

40 Ibid.; Hutchison, Political history, p. 32 I.

41 NLS, GUA, 'minute book', General Committee, 30 Aug. I920, ACC. I0424/73. There is a degree of confusion over titles as the Unionist Association minutes clearly refer to this as a 'new body', while there would appear to be a definite connection with the Good Government Committee first established in I9I9.

42 Glasgow Herald, 30 Sept. I920.

43 NLS, GUA, 'minute book', General Committee, 26 Nov. i919, ACC. 10424/73.

44 NLS, Shedden, 'municipal file', ACC. I0424/9 (xii).

45 NLS, GUA, 'minute book', General Committee, 30 Sept. I920, ACG. I0424/73; Shedden, 'municipal file', ro424/9 (xii). 
the Conservative party eventually decided to contest elections under its own banner. $^{46}$

If the liberals remained a significant force in local politics in Edinburgh, it is difficult to see them as other than very junior partners in Glasgow. The split in the party was only formalized in 1920 and their organization deteriorated rapidly thereafter. ${ }^{47}$ The only liberals successful in the I9I8 general election in Glasgow were coalition liberals but, by I922, their constituency organization throughout Scotland 'was regarded as a paper fiction' ${ }^{48}$ Certainly the liberals were involved in the GGL. The original decision, 'to form an organisation non-political but anti-Socialist', was taken jointly by the GUA and the coalition liberals, and the chairman of the league was a prominent national liberal, P. M. Martin. ${ }^{49}$ Although some liberals withdrew and others did not join because they did not want to alienate labour voters at the forthcoming temperance referendum, it would appear that most liberals were happy with the arrangement. ${ }^{\mathbf{5 0}}$ However, gauging the extent of their practical contribution is more difficult and it would appear that their main role lay in helping sustain the fiction that the moderates were 'non-political'.

The original constitution of the Municipal Electors' League was regarded by the GUA as too 'nebulous and vague'. While they were prepared to sacrifice doctrinal clarity for the sake of unity, the unionists pressed for a more definite statement of opposition to socialism which, after all, "was the principal object for which the formation of such a League was originally proposed' ${ }^{51}$ The unionists held sway and the league agreed to a new, explicitly anti-socialist clause in its constitution, even though this led to the withdrawal of one of the constituent groups. ${ }^{\mathbf{2}}$ Why the league was dissolved and replaced by the Good Government Committee is not clear, as there does not appear to have been any change in policy, which remained that of consolidating the 'moderate' forces in the fight against labour, in particular avoiding moderate candidates standing against one another. In the run-up to the election the Glasgow Herald described the league as 'composed of representatives of the leading political parties, Unionist, Liberal and Liberal Coalition, and of commercial, social, educational and religious agencies'. 53

46 The terms 'Moderate' and 'Progressive' were basically interchangeable. In Edinburgh, the Progressive party was formed in I928 and in Glasgow the moderates became the progressives in I936. Miller, 'Politics in the Scottish city', p. I99.

47 'The most derelict of all areas was Glasgow itself.' Cook, Age of alignment, p. 35.

48 Hutchison, Political history, p. 32 I.

49 NLS, Shedden, 'municipal file', ACC. I0424/9 (xii); Glasgow Herald, 6 Oct. I920, 22 Feb. I929.

50 NLS, Shedden, 'municipal file', ACC. I0424/9 (xii). The I920 municipal election was held simultaneously with a poll to determine the licensing arrangements in every war. Most wards voted against the local veto and in favour of 'no change'. See McLean, Legend, pp. 182-3.

51 NLS, GUA, 'minute book', General Committee, 26 Apr., 3 May i920, ACC. I0424/73.

52 This was the Citizens' Vigilance Association which was regarded by the Unionists as a Liberal body. NLS, GUA, 'minute book', General Committee, 3I May i920, ACG. I0424/73.

53 Glasgow Herald, 2i Oct. I920. 
Labour made significant gains in 1920, winning seats in 18 of the City's 37 wards, giving it 44 councillors out of a total of in elected, and presaging the stunning success to come in the 1922 general election. However, given that the unionists had feared labour was bidding 'to rule the city', the result was little short of a triumph for the whole strategy of the moderate alliance.

When the GGL was established on a permanent basis, the GUA decided not to affiliate.$^{54}$ However, this decision did not represent a break in the broad front approach or herald a move to running unionist candidates. Rather, the GUA, through its own local elections sub-committee, co-operated with the GGL. The closeness of the relationship can be seen during the I925 polls. The two organizations agreed that the GUA issue to its membership (between 20,000 and 25,000) its own circular and the manifesto of the league, with the recipients being 'asked to make themselves active in their own and neighbouring Wards, and to assist on polling day'. ${ }^{55}$

Virtually all anti-labour candidates were designated 'moderate' but the party as such only existed within the Council chambers. ${ }^{\mathbf{5}}$ Neither was the GGL a surrogate party, as it had no full-time officials and concentrated its activities on the period immediately prior to the polls. ${ }^{57}$ Its main function was to select suitable candidates and to ensure that moderates did not stand against one another. In this it was largely successful and in the I920s it was labour which was more likely to suffer from a split vote due to the competition from left-wing parties. After the election of 1920 it was 1926 before rival moderates faced each other in contests involving labour. The split in the Sandyford ward allowed labour to win the seat (for the first time) on a minority vote. The Glasgow Herald railed against this result especially as the candidate recommended by the GGL got I,ooo votes more than his moderate rival. ${ }^{58}$

Anti-socialism may have been an essentially negative message but it was certainly effective. Unlike in parliamentary elections, labour proved incapable of achieving a municipal majority. Rather than making continual progress after I920, labour had apparently reached a plateau. There was little change in the overall complexion of the corporation with the partial exception of I926. In that year, galvanized by the General Strike and the miners' lockout, labour made eight clear gains and pushed its representation to new heights. However, unlike in Sheffield where 1926 did prove to be the turning point when labour secured control of the Council, in Glasgow there was no breakthrough and labour lost most of its gains the following year. ${ }^{59}$ In 1930 the Glasgow Federation of the

\footnotetext{
${ }^{54}$ NLS, GUA, 'minute book', General Committee, 30 May I92I, ACC. I0424/73.

${ }_{55}$ Ibid., 25 Oct. I925.

56 'The name Moderate has been adopted as covering all opponents of the Labour Programme'. Glasgow Herald, 3 Nov. 1920.

58 Glasgow Herald, 4 Nov. 1926.

${ }^{59}$ For Sheffield see Thorpe, 'Consolidation', pp. 86-8, and H. K. Hawson, Sheffield: the growth of a City, ${ }^{8} 83^{2-1926}$ (Sheffield, I968), pp. 286-99. For Glasgow and the political impact of the General Strike see Smyth, Labour in Glasgow, pp. 107-9.
} 
Independent Labour Party (ILP), looking back on a decade of trying to wrest control of the Council from the moderates, sadly concluded, 'No progress had been made since 1920. ${ }^{60}$

\section{V}

What were the factors, therefore, that lay behind the success of the moderates? One was the actual electoral system. Apart from the most obvious discrepancy between the age of qualification for men and women, there remained the business or plural vote, and the separate university seats. ${ }^{61}$ There was also the significant difference between the parliamentary and municipal franchises.

Whereas the Representation of the People Act established residence as the qualification for the parliamentary vote, occupation remained the qualification for the municipal vote. ${ }^{62}$ Of particular importance for our purposes here was the difficulty young single men had getting on the municipal roll; only I million of the 4 million men given the parliamentary vote under the terms of the I9I8 reform also qualified for the municipal vote. According to Tanner, this discrepancy did not matter since there was no class bias operating: 'As contemporaries agreed, it was single people, of all classes who failed to qualify for the municipal franchise. ${ }^{63}$ Elsewhere Tanner has compared municipal and parliamentary election results in 1922 for a group of English and Welsh constituencies and four Glasgow divisions. He estimates that labour polled between I and 2 per cent better in parliamentary contests and the conservatives between I and 2 per cent worse in municipal contests, and links this to the former's greater 'appeal to the young, ${ }^{64}$

However, a detailed examination of the difference between municipal and parliamentary electoral registers has been undertaken by Davies in his study of labour in Liverpool. While careful not to assume that being working class automatically translated into voting labour (especially in Liverpool) he does suggest that it was 'working-class voters who were more likely to be excluded from the municipal franchise', and that such exclusion 'was more likely to disadvantage labour than any other party ${ }^{65}$ Moreover, Davies also examines municipal ward boundaries and size of electorates, and clearly shows that labour strongholds had substantially higher electorates than those wards they were weakest in. ${ }^{66}$ An examination of the Glasgow wards shows a similar broad picture. By contrasting the ten wards which labour was most successful in during the I920s with the

60 Glasgow ILP Federation, 'minute book', Management Committee, 23 May i93o. Mitchell Library, Glasgow 89i745.

61 M. Dyer, Capable citizens and improvident democrats: the Scottish electoral system, I884-I929 (Aberdeen, I996), p. I05. $\quad 62$ M. Pugh, Electoral reform in war and peace, I9o6-I9I8 (London, I978), p. II2.

${ }^{63}$ D. Tanner, Political change and the Labour party, Igoo-I9I8 (Cambridge, I99o), p. 389.

64 D. Tanner, 'Elections, statistics, and the rise of the Labour party, I9o6-I93I', Historical Fournal, 34 (I99I), pp. 883-9o8, at pp. 906-7.

65 S. Davies, Liverpool labour: social and political influences of the development of the Labour party in Liverpool, I9oo-I939 (Keele, I996), pp. I25-6.

66 Ibid., pp. IOI-9. 
fourteen wards where the moderates won every single seat over the same period, we can see that labour wards had noticeably higher electorates and numbers of voters per seat. In 1922 the number of voters per seat in the labour and moderate wards were 4,743 and 3,984 respectively, though six years later, the gap had been reduced: 3,894 compared with $4,286 .{ }^{67}$ Labour was, therefore, underrepresented but not to the same extent as in Liverpool where the difference was much greater and grew wider over the same period.

However, labour's main complaint was over qualification for the franchise which it clearly felt deprived the party of potential votes. The Scottish council of the Labour party took issue with the I9I8 legislation over the treatment of lodgers, and claimed that the situation was worse than before. Labour also pointed out the absurdity of single and married women being treated differently and was to call repeatedly for a simplified register based on adult suffrage for national and local elections. ${ }^{68}$ William Regan, the Glasgow ILP organizer and a town councillor, spelt out the electoral impact much more clearly:

The Parliamentary register is infinitely more favourable to Labour than the Municipal Register. Thousands of young men (and they are usually Labour supporters) are entitled to the Parliamentary vote on reaching 21, but are disfranchised at the local poll through the absence of a property qualification. Again, in the middle-class parts of every Ward there are large houses comprising young ladies who qualify for the Municipal vote through their property, but who being under 30 years have no Parliamentary vote. These well-to-do young ladies are usually anti-Labour. ${ }^{69}$

Regan's arguments were based on a close knowledge of the city's electoral registers in which there were always some tens of thousands fewer municipal voters than there were parliamentary. This was partly due to the fact that some parts of the municipal burgh lay out with the parliamentary boundaries. However, there were interesting variations between the different parts of the city. In middle-class areas there was little discrepancy between the two electorates, if anything more people had the municipal vote than the parliamentary, and all the middle-class wards had a majority female electorate. ${ }^{70}$ In contrast the working-class areas had considerably fewer people on the municipal register compared to the parliamentary and these wards had a predominantly male electorate. There are inter-related matters of class, gender, and age involved here, but it is interesting to note that Regan's view of young men being labour-inclined gives support to the recent article by Childs on the propensity of young workers to vote labour. ${ }^{71}$

${ }^{67}$ Figures taken from the Glasgow Post Office Directory 1922-3 and 1928-9.

68 Scottish Advisory Council of the Labour Party, Report of Fourth Annual Conference I9I8, p. 4. See also Report I9I9, pp. II, 45-6, and Report I92I, p. 37. This contrasts with the virtual silence of labour in Liverpool over the electoral system. See Davies, Liverpool labour, pp. I53-63.

69 Forward, i3 Nov. I920; Brown, 'Labour party', p. I42.

${ }^{70}$ High female electorates were a sign of middle-class areas. See J. Turner, British politics and the Great War: coalition and conflict, 1915-I9I8 (London, I992), pp. 412-I4.

${ }^{71}$ M. Childs, 'Labour grows up: the electoral system, political generations, and British politics, ı890-I929', Twentieth Century British History, 6 (I995), pp. I23-44. 
Labour in Glasgow certainly felt that the franchise had direct political consequences. The Maryhill division comprised three wards that proved to be stony ground for labour at local elections in the ig2os. In one labour never managed a single victory, and in the other two only occasional successes. In contrast, labour secured the parliamentary seat in I922, I923, and I929. The unionist victory in 1924 was due to liberal non-intervention, but there was more to it than that. In I922 labour calculated that, on the basis of municipal results, it could expect a vote of over Io,ooo. However, in addition to these municipal voters, there were an additional 3,640 category ' $\mathrm{D}$ ' electors in the division, that is 'young men who have only the Parliamentary vote'. Labour felt 'confident of capturing the young men's vote', and its calculations proved to be accurate as it took the seat with I3,058 votes. ${ }^{72}$ A similar pattern occurred in the constituencies of Camlachie and Tradeston; the moderates dominated the municipal wards but Labour took both divisions at all four general elections in the Ig2os.

Maryhill and Camlachie both had a middle-class ward where labour rarely bothered to challenge, whereas Tradeston had two wards - Kingston and Kinning Park - which were always contested. Labour lost regularly in the latter, and shared the representation in the former. However, labour held the parliamentary seat by large majorities throughout the I920s, whether in three-way contests or straight fights with the unionist. In 1922 labour polled 55.7 per cent at the general election but only $48 \cdot 8$ per cent at the municipal contest. In 1924 the respective labour polls were $56 \cdot 0$ per cent compared to $50^{\circ} 3$ per cent, and in $192957^{\circ} 9$ per cent compared to $51^{1} 5$ per cent. ${ }^{73}$ This gap ( $5^{-7}$ per cent) between labour's share of the parliamentary and municipal polls is significantly larger than that identified by Tanner, and suggests that the exclusion of young male workers from the local franchise may have played a crucial role. Another gap existed, that between the turnout in national and local elections. Since municipal polls could be up to 20 per cent less that parliamentary, it may be that this could explain labour's weaker performance in the former. Direct comparisons are problematic because of the number of uncontested returns in middle-class wards, but examination of Kingston and Kinning Park which were contested every year would suggest that turnout had little, if any, direct impact upon results. $^{74}$

If the vagaries of the electoral system favoured the moderates, that was not the only reason for their success. The party achieved a high degree of unity and discipline through the gentlemen's agreements achieved via the GGL and, as

${ }^{72}$ Forward, 2 Dec. 1922.

${ }^{73}$ Election data taken from Craig, Parliamentary election results, and Glasgow Herald.

${ }^{74}$ Labour's single victory in Kinning Park between I92I and I93I occurred on a poll of $57 \cdot 3$ per cent, compared to an average poll of $56 \cdot 0$ per cent. In Kingston labour's seven victories were achieved on an average poll of $57^{\circ} \mathrm{o}$ per cent, while the moderates' four victories were secured on an average of 58.5 per cent. Tanner has commented on the different turnout between national and local politics, and does not find it a convincing explanation of labour's better performance at parliamentary elections. Tanner, 'Rise of labour', p. 907. 
we have seen, it was rare for rival moderates to stand against one another. The effectiveness of the GGL and the GUA in placing candidates meant that labour always had to defend its seats, whereas the moderates enjoyed a large number of uncontested returns. At the same time labour suffered from split votes more often, as in 1927 when it lost in Govan and Parkhead, both traditional strongholds. ${ }^{75}$

It is clear that, in Glasgow as in other urban centres in Britain, local politics became polarized very quickly after the war. This was so in Sheffield where the 'Citizens' Alliance, uniting conservative and liberal, stood so firmly on middle-class lines. ${ }^{, 76}$ It was also the case in other towns where no 'front' party was formed. Davies and Morley have commented on this period that 'the significance of class in municipal politics stands out', and this was the case regardless of what form the various anti-labour alliances took. ${ }^{77}$ The geographic manifestation of this political antagonism was expressed in the affiliation of the various wards of the city. Labour and the moderates entrenched themselves in particular heartlands; labour in what were clearly working-class districts and the moderates in middle-class, residential areas. However, two points are important to note. One is that the moderates had a significantly larger number of secure seats than did labour; fourteen wards returned moderates exclusively throughout the I920s, while only five were similarly labour inclined. Secondly, there were a number of working-class wards where the moderates could and did win seats on a regular basis, and we shall discuss these in more detail below.

In the absence of other census data at the ward level, particularly on occupations, housing conditions can be utilized to provide a correlation between class and politics. ${ }^{78}$ The number of persons per room for I92 I related to the political loyalties for each ward over the period 1920-30 illustrates an expected relationship. As Table I shows, the fifteen wards with the lowest number of persons per room (i.e. lower than the figure for the whole burgh) were all solidly moderate, while the ten wards with the highest number of persons per room (or greatest degree of overcrowding) were either solidly or predominantly labour. ${ }^{79}$ In the fifteen better housed wards, the moderates won every single seat bar two at the municipal elections between 1920 and 1930. To these need to be added Exchange, part of the business centre with a high level of plural votes, and exclusively moderate, and Kinning Park, where labour's single success was in the exceptional year of i926. In the ten worst housed wards, labour enjoyed solid success in six while it was only predominant in the other four. In these the moderates could and did make occasional gains.

\footnotetext{
75 An account of the moderate candidate's unexpected victory in Parkhead is given in his autobiography. Captain H. J. Moss, Windjammer to Westminster (London, I94I), pp. I3 ${ }^{\mathrm{I}-8 .}$

76 Thorpe, 'Consolidation', p. 86; see also Mathers, 'City of Sheffield', p. 76.

77 Davies and Morley, 'County borough elections', p. 654 .

78 See Cook, Age of alignment, pp. 83-4; and Miller, 'Politics in the Scottish city', pp. 202-3. Both authors use census data on numbers of persons per room.

79 Data taken from Report on the Thirteenth Census of Scotland, I, Part 2: City of Glasgow, p. 53, Table 4.
} 
Table I Glasgow municipal wards, housing conditions, and political loyalties, 1920-1930

\begin{tabular}{|c|c|c|}
\hline Ward & $\begin{array}{l}\text { Persons per Ioo } \\
\text { windowed rooms }\end{array}$ & Party \\
\hline Kelvinside & 68 & Mod \\
\hline Pollokshields & 82 & Mod \\
\hline Park & 95 & Mod \\
\hline Langside & IO4 & Mod \\
\hline Cathcart & 105 & Mod \\
\hline Camphill & $\operatorname{Iog}$ & Mod \\
\hline Dennistoun & I39 & Mod \\
\hline North Kelvin & I 49 & Mod \\
\hline Pollokshaws & I5O & Mod \\
\hline Blythswood & I5I & Mod \\
\hline Whiteinch & I5I & Mod \\
\hline Partick East & I56 & Mod \\
\hline Sandyford & I58 & Mod \\
\hline Partick West & I62 & Mod \\
\hline Govanhill & $\mathrm{I} 73$ & Mod \\
\hline City of Glasgow & $\mathbf{1 7 9}$ & \\
\hline Townhead & I88 & $\mathrm{M}^{*}$ \\
\hline Exchange & I92 & Mod \\
\hline Woodside & I97 & $\mathrm{L}^{*}$ \\
\hline Kinning Park & 202 & Mod \\
\hline Gorbals & 207 & $\mathrm{Lab}$ \\
\hline Kingston & 207 & $\mathrm{~L}^{*}$ \\
\hline Whitevale & 212 & $\mathrm{M}^{*}$ \\
\hline Anderston & 213 & $\mathrm{~L}^{*}$ \\
\hline Ruchill & 216 & $M^{*}$ \\
\hline Fairfield & 217 & Lab \\
\hline Govan & 217 & $\mathrm{Lab}$ \\
\hline Maryhill & 217 & $M^{*}$ \\
\hline Springburn & 219 & Lab \\
\hline Calton & 224 & $\mathrm{~L}^{*}$ \\
\hline Cowlairs & 226 & $\mathrm{~L}^{*}$ \\
\hline Cowcaddens & 230 & $\mathrm{~L}^{*}$ \\
\hline Shettleston & 233 & Lab \\
\hline Parkhead & 235 & $\mathrm{Lab}$ \\
\hline Provan & 243 & $\mathrm{~L}^{*}$ \\
\hline Hutchesontown & 252 & Lab \\
\hline Mile End & 264 & Lab \\
\hline Dalmarnock & 272 & Lab \\
\hline
\end{tabular}

Lab $=$ wholly or almost wholly Labour

Mod $=$ wholly or almost wholly Moderate

$\mathrm{L}^{*}=$ representation divided but mostly Labour

$\mathrm{M}^{*}=$ representation divided but mostly Moderate

Source: Report on the Thirteenth Census of Scotland, I, Part 2: City of Glasgow, p. 53, Table 4. 
While housing conditions seem to explain the conflicting political loyalties in the different areas of the city, they do not explain everything. ${ }^{80}$ Of particular concern are the marginal wards that lay between the two extremes, because it was here where political control of the city lay ultimately. Unlike in English municipalities, the complexion of the corporation was not confused by the presence of aldermen; other than the elected councillors there were only two ex-officio members. There were thirty-seven wards returning in elected members; seventeen safe wards left the moderates just short of a majority, but they were usually more than twenty seats ahead of labour. It was their ability to regularly win seats in what were largely working-class areas that secured moderate control.

For instance, Provan was more or less equally divided between moderate and labour in the I920s, yet it had the fourth highest level of overcrowding in the city. Other predominantly working-class wards with higher than average overcrowding where the moderates enjoyed the majority representation were Townhead, Whitevale, Ruchill and Maryhill. Maryhill had exactly the same number of persons per room as did Fairfield and Govan $(2 \cdot 17)$ yet, while they were solidly labour, Maryhill returned a moderate at every poll bar one between I92I and I93I.

It is clear that there was a significant working-class unionist vote in Glasgow. Part of that unionist identity comprised an instinctive antipathy towards the Irish or, to be more precise, the Catholic-Irish. Orangeism had long been a crucial element to working-class toryism, with the Orange order having direct representation on the western division and Glasgow association. ${ }^{81}$ Although this formal relationship came to an end in 1922 when the Orange order withdrew in protest at the signing of the Anglo-Irish Treaty, and there is evidence of the unionists distancing themselves from the Orange die-hards in order to better cultivate middle-class liberals, the link was to remain strong even after $1922 .{ }^{82}$

There is a popular tendency to associate the ethnic and racial sectarianism in Glasgow as a working-class phenomenon, sustained by the rivalry between the two big football clubs of Rangers and Celtic, but in the inter-war period anti-Irish prejudice became much more pronounced and cannot be identified solely with plebeian Orangemen. Prominent politicians, churchmen, intellectuals, even the aristocracy all contributed to the growing perception of the Catholic-Irish as a threat, not just to the established Protestant religion, but to the 'Scottish race' itself. The sources of what was an increasingly bitter intolerance were varied.

\footnotetext{
${ }^{80}$ See Smyth, Labour in Glasgow, pp. 30-I, for a more detailed picture of the municipal wards.

${ }^{81}$ Hutchison, Political history, p. 23; J. Mitchell, Conservatives and the union; a study of Conservative party attitudes to Scotland (Edinburgh, 1990), p. 39: E. McFarland, Protestants first: Orangeism in nineteenth century Scotland (Edinburgh, I990), p. 213.

${ }^{82}$ G. Walker, 'The Orange Order in Scotland between the wars', International Review of Social History, 37 (1992), pp. 185-9.
} 
Anti-Gatholic and anti-Irish feelings were hardly new to Scotland. Traditional Presbyterian hostility to the papacy, concern at the apparently ingrained poverty of Irish immigrants, and the increasing importance of the Home Rule question all served to make the matter a live issue prior to igi4. After the Great War, however, it was to become more significant. ${ }^{83}$

In spite of the fact that the Irish-Catholic community was as eager in its patriotism as everyone else during the conflict, the Easter Rising made Irish a synonym for treachery. Support for Sinn Fein in I918 and the subsequent War of Independence only served to confirm this judgement. Moreover, the I9I8 Education Act, which brought Catholic schools within the state system in Scotland while guaranteeing their religious character, provoked considerable opposition, expressed in the cry of 'No Rome on the Rates'. Although the Labour party had no responsibility for the Act, its general willingness to accept the reality of denominational schooling encouraged an identification of labour and Catholic. In addition, a constant refrain at the time was the direct link between industrial and political militancy and Irish republicanism.

The Church of Scotland was intensely anti-labour during the inter-war years and blamed the Irish for returning the 'Clydeside' group of MPs in I922, as well as identifying the labour leadership as mostly Irish ${ }^{84}$ Similarly, Sir Robert Horne, speaking about the 'Irish invasion' just before the 193 I election, declared that the Irish accounted for 25 per cent of the population of Glasgow but caused most of the city's problems. They were

responsible for the class of representation they got, and most of the trouble which arrived in their midst ... There were very few people who wanted to come to the Clydeside to establish industries unless they could demonstrate that they were not being over-ridden by the Irish revolutionaries in their midst. ${ }^{85}$

It must be emphasized that these views were not the expressions of a small minority of unionist politicians and conservative churchmen. Such attitudes were commonplace and, indeed, can be seen as forming part of the 'commonsense' of unionist and middle-class opinion. Throughout the rg20s and I930s there was a continuous church-led campaign against Irish immigration. The term 'invasion' was constantly employed and claims made that Irish labourers were being given jobs ahead of Scottish workers, and that Irish paupers were deliberately targeting Scottish parish councils. ${ }^{86}$ Despite the fact that the numbers of Irish immigrants were utterly insignificant after the war, the economic depression provided the soil in which sectarianism could flourish and become politically significant in a way it had never been previously.

${ }^{83}$ See T. Gallagher, Glasgow the uneasy peace: religious tension in modern Scotland (Manchester, I987), p. I36; S. J. Brown, "OOtside the covenant": the Scottish Presbyterian churches and Irish immigration, I922-I938', Innes Review, 42 (I99I), pp. I9-45.

${ }^{84}$ Brown, 'Outside the Covenant', pp. 26-8; and S. J. Brown, 'The social vision of Scottish Presbyterianism and the Union of I929', Records of the Scottish Church History Society, 24 (I992), pp. 92-3.

85 Glasgow Observer, 24 Oct. I93I.

86 Brown, 'Outside the Covenant'. 
Many leading unionists were also active Orangemen, such as Sir Charles Cleland, Archibald McInnes Shaw, grand master of the Order in Scotland and Unionist MP, and Sir John Gilmour, secretary of state between I924 and I929. Others, such as Lord Scone, were renowned for their bigotry. Many churchmen played a prominent role in the order which shared many of the same political concerns expressed by the Protestant churches. Thus the order was violently opposed to industrial militancy and to the Labour party, it associated bolshevism with catholicism, campaigned against the I9I8 Education Act, and called for 'Scots' workers to be given preference over the 'Irish'. ${ }^{87}$ Orangeism cannot be equated with Protestantism - if that were the case, Labour would never have won any seats in Scotland. And it would appear that the 'Orange' vote, like the 'Irish' in Scotland, was not so monolithic or as easily directed by its leaders as those leaders would have liked to think. ${ }^{8}$ None the less, in identifying a working-class pro-unionist and pro-moderate vote, the religious question would appear to be critical.

Hostile references to Irish Catholics occur frequently within the unionist minutes. Just as in the churches, complaints were made about the numbers of Irish coming to Scotland, becoming chargeable to the parish, or getting work with the corporation. ${ }^{89}$ Regardless of the lack of evidence it was stated as fact that Irish migrants were given preferential treatment in employment and were a drain on the poor rate. It was questioned whether encouraging emigration as a response to long-term unemployment was a wise idea since it left, 'an open field for the Irish, whose desire it was to gain the country for Roman Catholicism' ${ }^{\mathbf{9 0}}$ Neither the unionists nor moderates were sectarian organizations. There were no formal barriers to Catholics joining or being selected as candidates. But neither case was very likely or likely to lead to success. In I930 there was a complaint about the selection by the GGL of a Catholic to stand in Govan, and it was claimed this had cost, 'many Protestant votes'. ${ }^{91}$

\section{I}

At the beginning of the I93os the moderate majority remained secure, but there were certain indicators that it was not as impregnable as before. It was becoming more difficult to get candidates to contest labour's more secure seats. Although these were usually hopeless from the moderate point of view, keeping labour on the defensive was regarded as a civic duty, and it was good experience for young men who were interested in political careers. ${ }^{92}$ Moreover, finance was harder to come by. More and more moderate candidates now expected to have their election expenses paid rather than meet them out of their own pocket. The

\footnotetext{
87 Walker, 'Orange Order', pp. I82-5.

${ }^{88}$ Ibid., pp. I89-94. On the Irish vote see Smyth, Labour in Glasgow, ch. 4.

89 NLS, GUA, 'minute book', General Committee, 29 Nov. I926, ACC. I0424/73.

90 Ibid., 29 Aug. I927. 91 Ibid., 24 Nov. I930.

92 Ibid., 25 Feb., 7 Oct., 28 Oct. I929; Hutchison, Scottish politics, p. 47.
} 
GGL therefore had greater demands placed on it and, in turn, was less able to help the Unionists as it normally did. The death of Martin, the Liberal who, 'for many years had been the backbone' of the league, made matters 'critical' ${ }^{93}$

The incipient crisis was not just financial. Successful as they had been in saving Glasgow from socialism, the moderates had been helpless in halting the inexorable decline of the 'Second City'. The almost permanent depression that had settled over the capital goods sector placed the corporation in a desperate position, as social expenditure rose dramatically, while the local tax base shrank. Business opinion grew increasingly critical of the perceived 'extravagance' of Glasgow's spending.

The demand for economy was nothing new, it was the raison d'être of the original moderate alliance after all, but the complaints became more insistent and critical. The major issue around which middle-class opinion united was the rates. The moderates had proven their worth by reducing the total combined municipal rate bill from an historic high point in the immediate post-war years. However, by the later ig2os the rates had begun to creep up again, and in early I928, the Glasgow Chamber of Commerce was calling not only for retrenchment in civic expenditure, but the appointment of an outside 'expert' to oversee the financial administration of the corporation. The failure of the corporation to respond - it simply let the Chamber's resolutions 'lie on the table' - caused something of a crisis in relations between the two bodies. ${ }^{\mathbf{9 4}}$

Once the impact of the Great Slump kicked in, the city's already bad unemployment figures worsened dramatically with a concomitant increased pressure upon public services. The moderates were facing the same dilemma locally as the Labour party was nationally, and like the government it faced political constraints and consequences whatever decisions it took. For the majority of moderate councillors sitting in safe middle-class wards, there was plenty to be gained by supporting calls and initiatives for cuts in expenditure and, therefore, lower rates. Moderates who represented working-class constituencies, however, had to be more circumspect and balance general support for 'economy' with responsiveness to specific working-class issues.

Such latent tensions came to a head in 1930 over the issue of granting twelve days paid holiday for municipal employees. At the usual moderate group meeting a decision was taken to oppose the proposal, but at the subsequent corporation meeting ten councillors broke ranks and voted in favour. This threatened the whole basis of the party as loyalist members publicly questioned the sense of maintaining their allegiance in such a situation and others threatened to 'act on their own'. ${ }^{95}$ Three members were expelled from the party, even though in their defence it was stated that the extent of the dissension had been made clear and it was known there would be 'a considerable defection' at the vote. ${ }^{96}$ The

93 NLS, GUA, 'minute book', General Committee, 25 Feb. 1929, ACC. I0424/74.

94 Glasgow Herald, 28 Feb., 27 Mar. I928. $\quad{ }_{95}$ Ibid., I4June I920.

96 Ibid., i9 June r930. 
expelled councillors represented the wards of Cowlairs, Whitevale, and Govanhill. Cowlairs was predominantly labour where the single moderate councillor was defending his seat, Whitevale was predominantly moderate, but with worse overcrowding than the Gorbals, and Govanhill was a safe moderate ward which had been a long-term target of labour.

By 1933 relations between the moderates and their core middle-class supporters were becoming poisonous. The rate was set in August and, in spite of identifying some minor economies, the corporation was circumscribed by its statutory obligations, especially over public assistance, and an increase of is $6 d$ was announced. Business opinion was outraged with the Glasgow Property Owners' and Factors' Association particularly vociferous and it helped launch a campaigning body, the Glasgow Association for Rents Reduction and Civic Efficiency. There was some recognition of the extent of the unemployment problem and the need for national government to absorb more of the financial burden; however, the most popular demand involved an extension of the old Chamber of Commerce demand that government appoint commissioners to take control of the corporation. $^{97}$

\section{I I}

The moderates, therefore, were in a quandary. In order to retain power they had to win at least some of the working-class wards, but the worsening economic conditions and the insistent middle-class demands for retrenchment made it much more difficult to maintain their support in every area. Into this increasingly tense situation entered the nemesis of the moderates in the unlikely shape of one Alexander Ratcliffe, head of the militantly anti-Catholic Scottish Protestant League (SPL). Ratcliffe was first active in Edinburgh and was elected to the Education Authority there in 1925. At the 1929 general election he contested Stirling and Falkirk burghs as an independent, and, although coming last, polled over 20 per cent of the votes. The following year he moved to Glasgow, established his own church, and was soon to launch a political movement that was as significant as it was short-lived. ${ }^{98}$

The SPL ran three candidates at the local elections in I93I, winning two seats and securing over I2,00o votes. Success came in Dalmarnock, a safe labour seat, where Charles Forrester, an ex-communist, triumphed, and in Dennistoun, an equally safe moderate seat, where Ratcliffe topped the poll. Both major parties therefore had either as much or as little to be worried about. It was not clear exactly what long-term impact the SPL might have and the Glasgow Herald was

97 Ibid., II, I8, 22, 24 Aug., 28 Sept. I933.

98 The story of Ratcliffe and his SPL is expertly told in Gallagher, Uneasy peace, pp. I50-7. See also the same author's 'Protestant extremism in urban Scotland, I920-I939: its growth and contraction', Scottish Historical Review, 64 (I985), pp. I43-67; and S. Bruce, No Pope of Rome:anti-Catholicism in modern Scotland (Edinburgh, I985). 
satisfied simply to comment that the league's 'participation in the fray introduced the hot spirit of faction. ${ }^{\mathbf{9 9}}$

The moderate majority remained untouched and was given a boost the following year when, as a result of the ILP's decision to disaffiliate from the Labour party, civil war broke out in the Labour ranks. The majority of the Scottish ILP was opposed to disaffiliation and shortly after the Bradford Conference they set up the Scottish Socialist party (SSP), which took over the running of the Labour campaign. In twenty-one wards they faced their former comrades standing directly under the flag of the ILP. The consequences of this dispute could have been catastrophic but the overall 'left' representation did not fall. Labour and the ILP tended to cancel each other out and, in spite of the occasional spat, left each other alone with the latter having around ten councillors for the rest of the decade. ${ }^{\mathbf{1 0 0}}$

The $193^{2}$ contests were further complicated by a more substantial intervention by the SPL, which stood in eleven wards and won an extra seat. The real shock, and the SPL's lasting claim to fame, was to occur the following year. In the I933 elections the SPL stood in twenty-three wards, won four seats, and gained 23 per cent of the total vote. This represented a real show of strength which almost matched the performance of the moderates who polled only marginally more than the SPL, even though they stood in twenty-seven wards. For the ruling party the results were a disaster. They lost seventeen seats in total and overall control of the corporation. That labour was now in a position to form an administration came as a surprise. Prior to the election it had already put the blame for not achieving a majority firmly at the door of the ILP and the Communist party for creating 'criminal confusion' in the minds of the working-class electors by running their own candidates. ${ }^{\mathbf{1 0 1}}$ The labour victory or, to be more precise, the moderate defeat, was due overwhelmingly to one single factor, Ratcliffe and his league.

\section{I I I}

The moderates lost seventeen seats - an unprecedented number at a single election. Only in one ward - Provan - did labour win in a straight fight with the moderates. In all the others the intervention of the SPL proved crucial. The four seats gained by it were in safe moderate wards, three of which were not contested by labour or the ILP in I933. This may have been a deliberate tactic as labour was aware that the SPL threatened the moderates more, 'because of the rivalry for the Orange vote'. ${ }^{102}$ Damaging as it was for the moderates to lose these seats, more significant were the twelve wards lost to labour and the ILP due to SPL intervention.

In four of these wards labour was usually the dominant party, the moderates usually dominated another three, while the remaining five were essentially safe

99 Glasgow Herald, 4 Nov. I931.

101 Forward, 4 Nov. I933.
100 See Smyth, Labour in Glasgow, pp. 190-4.

102 Ibid. 
moderate wards. After the election Ratcliffe boasted that, 'if the Socialists have a majority in Glasgow Town Council, they have the Scottish Protestant League to thank for it'. ${ }^{103}$ The extent of labour's debt to the SPL can be gauged from the fact that in all twelve seats bar one, the combined moderate and protestant vote was greater than the winning labour or ILP vote. And in the one case, Maryhill, where labour had an overall majority, it was by six votes. In sharp contrast the SPL failed to register any gains against labour. There were five wards where labour or the ILP were the incumbents, targeted by the SPL. In none of these seats were there official moderate candidates, though independent moderates came forward in all bar Dalmarnock where, adding to the confusion, an independent protestant stood also. If this was a ploy by the moderates to encourage the SPL at the expense of labour it backfired badly. Though the SPL candidates polled heavily, labour and the ILP held their seats quite comfortably.

The scale of the SPL vote in a variety of wards showed that it was capable of attracting a wide range of support throughout the city. Invariably, the contests with the highest turnouts were those involving the SPL. The size of the 'protestant' vote in working-class wards and its victory in Dalmarnock in I93I, showed that labour could not afford to be too sanguine about the SPL threat to its own position. None the less, there can be little doubt that it was from among moderate electors that the SPL gained most of its votes. Six of its seven seats were in wards that, up to then, had been secure moderate seats and which have been described as 'lower middle class districts'. ${ }^{104}$ While wards such as Kinning Park and Govanhill were a mix of working class and lower middle class, Camphill, Cathcart, and even Langside, where the SPL polled heavily in I933, were more solidly middle class. Sectarianism was not, therefore, simply an expression of working-class antagonisms but enjoyed a healthy support in the genteel suburbs.

Having successfully established itself as the power broker in Glasgow's municipal politics, the SPL began to self-destruct. The only discipline on its councillors was that they vote together on religious issues. Otherwise, the majority, including Ratcliffe, normally voted with Labour while two usually supported the moderates. The main problem lay with Ratcliffe himself and his determination to retain absolute control of the movement. This led to personality clashes and four of his erstwhile comrades left and presented themselves to the electorate as independent Protestants. ${ }^{105}$ In 1934 the SPL only managed to field seven candidates and, though they all polled respectably, none were returned. Most damagingly of all, Ratcliffe lost his own seat in Dennistoun, though given a clear run by the moderates. Despite his claims to be a reformer, Ratcliffe came to an arrangement with the moderates prior to the November election. With the SPL disintegrating beneath him, Ratcliffe could not mobilize the same forces as the year before, while the moderates saw such a pact as necessary to regain the ground lost to

103 The Vanguard, I5 Nov. I933, quoted in NLS, Shedden 'municipal file', ACC. I0424/9 (xii).
104 Gallagher, Uneasy peace, p. I53. 
Labour. The unionists explained the arrangement as a means of 'avoiding a split of the Protestant vote'. ${ }^{106}$

However, the result was another disaster for the moderates with labour entrenching its hold on power. Labour took four seats from the moderates, while the ILP took one each from the moderates and protestants. For the moderates salt was rubbed in the wound when an ex-councillor and Kirk elder, standing as an independent moderate without labour or ILP opposition, and, with Catholic support, defeated Ratcliffe by 34I votes. ${ }^{\mathbf{1 0 7}}$ With this result the SPL more or less disappeared as a significant political force. Its remaining councillors and those who chose to label themselves independent Protestants were defeated in subsequent elections and Ratcliffe failed to get back on the Council when he was defeated in Camphill in 1937 .

The storm centre of militant Protestantism now shifted to Edinburgh where a new grouping, Protestant Action, led by one John Cormack, made its breakthrough just as the SPL was falling apart in Glasgow. More violent than the SPL, in 1936 Protestant Action gained over 30 per cent and relegated Labour to third place overall. Thereafter, Cormack overstretched himself and his movement rapidly declined, though he regained his seat on the Council and held it until I962. ${ }^{108}$

In Edinburgh the progressive majority over Labour was so massive that Protestant Action could barely dent it. What the moderates experienced in Glasgow, however, was a critical haemorrhage of key supporters. If we accept for the moment that the Glasgow unionists were correct in their view that there was a distinct 'protestant' vote which was pro-moderate, we can see that vote declining. In 1933 the combined moderate-SPL vote was $52 \cdot 5$ per cent but fell to $46 \cdot 4$ per cent in 1934. The combined labour-ILP vote on the other hand rose from $42 \cdot 8$ to 5I per cent. The almost compete disappearance of the SPL thereafter, however, was of only marginal benefit to the moderates. The strategy of attempting to unite the 'protestant' vote in 1934 had failed and it would appear that the SPL acted as a conduit for a significant number of electors to transfer their allegiance over to labour. This becomes more apparent when we look at the political complexion of particular wards.

A number of the wards lost by the moderates either to the SPL or to labour quickly returned to the fold with the demise of Ratcliffe's party. These were middle-class wards, Camphill, Cathcart, Dennistoun, Pollokshaws, Whiteinch, which had been solidly moderate and became so again almost immediately. In Partick West and Whitevale, which had large working-class populations, representation became divided between the two parties. Of more significance are those wards that were lost to labour in I933, courtesy of the SPL, and remained labour thereafter. This group comprised Kingston, Kinning Park, Maryhill,

\footnotetext{
${ }^{106}$ NLS, GUA, 'minute book', Local Elections Sub-committee, 22 Oct. 1934, ACG. 10424/74.

${ }^{107}$ Gallagher, Uneasy peace, pp. ${ }^{5} 5^{6-7}$.

${ }^{108}$ For a detailed account of Protestant Action see T. Gallagher, Edinburgh divided (Edinburgh, 1987).
} 
Ruchill, Townhead, and Woodside. Two of these wards had been more or less solidly pro-moderate, two had been predominantly moderate, and the remaining two had been predominantly labour with occasional moderate successes. After I932 the moderates never won a seat in any of them for the rest of the r93os. The presence of a large Orange vote in Maryhill had been regarded previously as a cause of labour's poor performance there. That labour now held the ward comfortably suggests that either significant numbers of protestant voters switched to labour or no longer saw voting moderate as an overwhelming priority.

While it is clear that local politics in Glasgow were primarily a struggle between labour and unionist, the strategy of the latter remained that of maintaining the moderate alliance. This became more difficult with the winding up of the GGL in $1933 .{ }^{109}$ The unionist response was not to run their own candidates but to seek to establish another such umbrella organization. To this end a Municipal Society was formed, although it was soon to exhibit the weaknesses of the GGL, namely that it had no full-time organization and only came sporadically to life in the weeks prior to the November polls. In 1936 the Municipal Society was in turn replaced by the Glasgow Progressive party with its own office and full-time staff. ${ }^{110}$ Attempts were made to involve prominent industrial figures, and in order to sustain the non-party basis of the new organization, Councillor James Gray, a liberal, was appointed chairman. ${ }^{111}$

Reflecting the common view that the GGL had failed to sustain enough campaigning between elections, the Progressive party started off with some very ambitious plans. There was to be a branch or 'unit' in every ward, special representation for 'youth' and for 'weekly wage earners'. Whatever the latter two points intended, the first was a step too far for the unionists. Keen as they were to co-operate in the struggle against labour, the plan for Progressive party ward committees sounded suspiciously like a direct political rival and the Unionist associations vetoed the idea. ${ }^{112}$ To all intents and purposes, therefore, the Progressive party was simply a continuation of the Moderate party.

The 1936 election was crucial since all the gains made by labour in I933 would have to be defended. The progressives made seven net gains, retaking all four SPL seats. Apart from winning Shettleston off the ILP, however, none of its gains was unexpected and labour still held on to the other wards it had taken three years before. A single progressive gain was made in 1937 but, with no change in I938, labour's majority remained secure on the outbreak of war.

\section{IX}

After the defeat of the moderates in 1933 the unionists, not surprisingly, laid the blame squarely at the door of the SPL, 'the large Socialist gains were not due to

\footnotetext{
109 NLS, GUA, 'minute book', General Committee, 9 Jan., 27 Mar. 1933, ACG. I0424/74.

110 NLS, Shedden 'municipal file', ACG. I0424/9 (xii), 'minute book', General Committee, 24 Feb. 1936, ACG. 10424/74. ${ }^{111}$ Glasgow Herald, I4 Sept. 1936.

112 NLS, GUA, 'minute book', Local Elections Sub-committee, 22 Dec. 1936, ACG. 10424/74.
} 
their own strength, but to the split in the Anti-Socialist vote through the intervention of the Scottish Protestant League'. ${ }^{113}$ The failure of the administration to deliver its promised economies and the increase in rates was recognized as having encouraged moderate supporters either to abstain or switch to the SPL as a protest. Other, more long-term or structural factors operating against the moderates were touched upon, and these were given greater attention the following year, after the electoral arrangement with the SPL had failed to turn the tide. Five 'main causes of defeat' were identified. These were the Catholic vote; corporation employees; council house tenants; people in receipt of public assistance; and 'the influence of the Co-operative Societies'. ${ }^{114}$

Recognizing the issues, however, did not mean that the unionists had any clear idea what to do about them. The Catholic electorate was regarded as uniformly hostile, but there was no strategy to appeal to it. The increasing numbers of Cooperative societies affiliated to the Co-operative party and therefore labour, had been giving the unionists cause for concern for some time. Periodic appeals were made to try to organize unionists who were co-operators to counter this politicization, but there is no evidence of any definite action being undertaken. ${ }^{115}$ Labour's increase of the 'dole' was seen as having made a major impact 'in very many Wards', but there was no mention of any response to this. If the moderates and unionists hoped the issue would just go away, they were to be disappointed: as late as January 1939 Glasgow's adult male unemployment rate stood at over 20 per cent. ${ }^{116}$

The corporation housing schemes were described as 'hotbeds of socialism', and it was assumed that the 'vast army' of public employees would be more sympathetic to labour. The terminology used indicates the essentially negative response, which ignored the fact that both phenomena had developed not under labour but under a moderate administration. In turn this illustrates the inherent weakness of the moderates. The unity of their purpose in opposing labour was where their strength lay, but this hid the lack of any distinctive political or administrative strategy. The core middle-class supporters wanted nothing more than economies and lower rates bills, but this was ultimately incompatible with the need to respond to working-class supporters as well as meet the statutory obligations placed upon the corporation. The sudden emergence of the SPL in the worst depths of the depression gave the anti-socialist voter an alternative to the moderates for the first time. However, given the economic conditions of the i93os in Glasgow, it is difficult to see how the moderate balancing act could have continued. The fact is that with the collapse of the SPL, the middle-class wards were regained whereas the crucial working-class wards were lost for good.

${ }^{113}$ NLS, Shedden 'municipal file', ACG. I0424/9 (xii).

114 NLS, GUA, 'minute book', General Committee, 26 Nov. I934, ACG. I0424/74, Shedden 'municipal file', ACG. 10424/9 (xii).

115 Ibid., 25 May 1925, 29 Mar. I926, 7 Jan. 1935, 30 Mar., 27 Apr. 1936.

116 The Glasgow figure was slightly above the Scottish total of 20 per cent adult men unemployed. See Ministry of Labour, Local unemployment index. 
The political fault lines in Glasgow in the inter-war period provide little evidence of the likelihood of any progressive alliance. The main issue for the middle class was how best to resist the advance of labour. At the parliamentary level this meant support for the Unionist party, as the liberals were revealed as a marginal force whose efforts at elections became increasingly sporadic and inconsequential. At the municipal level, co-operation between liberal and unionist developed out of a pre-existing tradition of 'no politics' that came to be seen as crucial in order to thwart labour's ambitions and secure moderate control of the corporation. The unity engendered between the two parties was rarely threatened. In I929 when hostility to the liberals at national elections was intense, the Glasgow unionists refused to sacrifice local unity. Faced with choosing between a liberal moderate and a unionist moderate, the GUA's decision was to make no recommendation rather than support their own man. ${ }^{117}$ It was only in 1938 that party politics intervened when five liberals stood against moderates: totalling well under 2,000 votes, they 'made a miserable show' ${ }^{118}$

The solidarity engendered by anti-socialism was strengthened further by antiCatholicism. This was hardly new to the west of Scotland but, in the early I920s, it became a more substantial and virulent phenomenon. This has been explained in relation to the ending of the short post-war boom and, with it, the collapse of confidence about Scotland's future. ${ }^{119}$ The Protestant churches, which led the campaign against the Irish, were as equally concerned at the perceived threat posed by socialism and, indeed, linked both together. Political realignment in the churches in the early ig20s saw conservative leaders reassert their authority and reject the calls for reconstruction that had been embraced by the General Assemblies during the war and immediately after. In this shift they enjoyed the support of their middle-class congregations. ${ }^{120}$

The Presbyterian churches were also involved in the setting up of the Moderate party and certainly the unionists shared their anti-Catholic prejudices. However, there were limits as to how far the moderates and unionists would use sectarianism as part of their political appeal. The closest they came to this was in I934 when they reached an agreement with the SPL at the municipal election. Yet, as we have seen, this backfired badly and there were moderates prepared to take on the SPL directly. In its internal post-mortem on the I933 defeat, the GUA affirmed that it 'is not a sectarian any more than it is a class party'. Moreover, it actually defended the very provisions of the rgr8 Education Act which fuelled the 'Rome on the Rates' propaganda of the SPL. ${ }^{121}$

117 NLS, GUA, 'minute book', General Committee, 28 Oct. I929, ACC. I0424/74. This dilemma occurred in the Cathcart ward.

118 Ibid., 28 Nov. I938. $\quad{ }^{119}$ Gallagher, Uneasy peace, p. I35.

120 Brown, 'Outside the Covenant', pp. ${ }^{22-5}$.

121 NLS, Shedden 'municipal file', ACC. I0424/9 (xii). The argument was threefold: that the Act remedied the injustice whereby Catholics paid education rates but got no benefits in return; that the religious instruction provided in non-denominational schools was 'Protestantism pure and simple'; and that religious education appropriate to both types of school was better than eliminating religious education altogether. 
The history of the Moderate party in Glasgow provides us with evidence of middle-class hostility to reconstruction and social reform. Whatever residual antagonisms Glasgow's liberals and unionists felt for one another, they were not sufficient to deflect both groups from concentrating upon the most important task in hand - keeping labour out of office. In achieving this aim, the moderates were aided by a more restrictive municipal franchise which limited the numbers of young working-class men on the voters' roll. However, to secure their majority the moderates had to win seats in wards that were predominantly working class and thus had to have an appeal to the working-class electorate. In part this was achieved specifically by moderate councillors in those wards being more responsive to working-class issues and needs. In part it was achieved by a general, shared ideology of anti-socialism and anti-Catholicism.

With the depression the moderates could no longer satisfy both their middleclass and working-class supporters, and a militant, politicized Protestantism provided a vehicle of protest against the perceived failures of the administration. Labour benefited in the short term from the split in its opponent's forces, which were more serious than its own divisions, and, in the longer term, from the transference of working-class votes. Having dabbled with the SPL, the moderates and unionists retreated from out and out sectarianism and reiterated their message of economy and anti-socialism. Relaunched as the Progressive party, the ambitious plans for organization and campaigns failed to come to fruition. Having identified the structural causes of their defeat, their response was essentially negative, and even anti-democratic. Secure as before in their suburban strongholds, none the less the glue that had bound together the class alliance was now dissolved. With it also dissolved the moderate majority. 